\title{
PRZYMUSOWE LECZENIE PSYCHIATRYCZNE W ŚWIETLE KONWENCJI ONZ O PRAWACH OSÓB NIEPEŁNOSPRAWNYCH
}

\section{WPROWADZENIE}

Przesłanki i tryb przymusowej hospitalizacji i leczenia psychiatrycznego ${ }^{1}$ uregulowano w ustawie o ochronie zdrowia psychicznego z 19 sierpnia 1994 r. ${ }^{2}$, która weszła w życie 21 stycznia 1995 r. Uregulowania tej ustawy, dopuszczające w określonych przypadkach przymusowa hospitalizację i leczenie psychiatryczne, wydawały się nie budzić zasadniczych wątpliwości co do ich zgodności z międzynarodowymi standardami praw człowieka. Jednakże wraz z uchwaleniem przez Zgromadzenie Ogólne ONZ 13 grudnia 2006 r. Konwencji o prawach osób niepełnosprawnych i jej wejściem w życie w polskim systemie prawnym w związku z jej ratyfikacja przez Prezydenta $\mathrm{RP}^{3}$ powstał istotny problem co do zgodności przepisów u.o.z.p., zezwalających na przymusowa hospitalizację i leczenie psychiatryczne, z Konwencją. Konwencja nie zezwala bowiem na przyjmowanie do szpitala psychiatrycznego pacjentów bez ich zgody ani na stosowanie w stosunku do nich przymusowego leczenia. Pogląd ten znajduje potwierdzenie w stanowisku powołanego na mocy Konwencji Komitetu ds. Praw Osób Niepełnosprawnych. Problem ten, tj. problem zgodności przepisów u.o.z.p. dopuszczających przymusową hospitalizację i leczenie psychiatryczne z Konwencja, jest przedmiotem rozważań w niniejszym artykule. Omówiono w nim odpowiednie regulacje u.o.z.p. i Konwencji, przytoczono stanowisko Komitetu ds. Praw Osób Niepełnosprawnych, a także przedstawiono pogląd autora negujący zgodność omawianych przepisów u.o.z.p. z Konwencją.

\section{REGULACJE U.O.Z.P.}

Przepisy u.o.z.p. zezwalaja na przyjęcie pacjenta chorego psychicznie do szpitala psychiatrycznego bez jego zgody w trzech przypadkach: po pierwsze, gdy jego dotychczasowe zachowanie wskazuje na to, że z powodu tej choro-

${ }^{1}$ Przez pojęcie przymusowej hospitalizacji rozumiem przyjęcie pacjenta bez jego zgody do szpitala psychiatrycznego, a przez pojęcie przymusowego leczenia - przymusowe podanie leków psychotropowych; artykuł dotyczy obu tych zagadnień.

2 T.jedn.: Dz. U. 2017, poz. 882 ze zm. (dalej jako: u.o.z.p.).

${ }^{3}$ Konwencja o prawach osób niepełnosprawnych weszła w życie w stosunku do Polski 25 października 2012 r. po jej ratyfikacji przez Prezydenta RP, Dz. U. 2012, poz. 1169 (dalej jako: Konwencja). 
by zagraża bezpośrednio własnemu życiu albo życiu lub zdrowiu innych osób (art. 23 ust. 1 u.o.z.p.). Przy czym przez osobę chora psychicznie rozumie się osobę wykazującą zaburzenia psychotyczne (art. 3 pkt 1 lit. a u.o.z.p.). W literaturze wskazuje się jednak, że w zakres pojęcia choroby psychicznej wchodzić będą również stany ciężkiej depresji z myślami samobójczymi, w których brak objawów psychotycznych ${ }^{4}$.

Drugi przypadek polega na przymusowej obserwacji pacjenta, który również zagraża własnemu życiu albo życiu lub zdrowiu innych osób, lecz nie ma pewności, czy jest chory psychicznie (art. 24 ust. 1 u.o.z.p.). Czas obserwacji ograniczony jest do 10 dni (art. 24 ust. 2 u.o.z.p.) i nie można w jej ramach stosować u pacjenta leczenia farmakologicznego (art. 33 ust. 4 u.o.z.p.). Jak słusznie wskazuje się w literaturze, osoba przyjmowana do szpitala psychiatrycznego na obserwację, wbrew literalnemu brzmieniu art. 24, nie musi wykazywać zaburzeń psychicznych ${ }^{5}$. Przyjęcie do szpitala psychiatrycznego w obu ww. przypadkach podlega następczej kontroli sądowej, w ramach której są bada spełnienie zarówno przesłanek formalnych, jak i materialnoprawnych ${ }^{6}$.

Trzeci przypadek przymusowej hospitalizacji reguluje art. 29 ust. 1 u.o.z.p., zgodnie z którym dopuszczalne jest przyjęcie do szpitala psychiatrycznego bez zgody osoby chorej psychicznie, której dotychczasowe zachowanie wskazuje na to, że nieprzyjęcie do szpitala spowoduje znaczne pogorszenie stanu jej zdrowia psychicznego, bądź która jest niezdolna do samodzielnego zaspokajania podstawowych potrzeb życiowych, a uzasadnione jest przewidywanie, że leczenie $\mathrm{w}$ szpitalu psychiatrycznym przyniesie poprawę jej stanu zdrowia. Przepis ten jest wyrazem mieszanego modelu medyczno-prawnego przesłanek przymusowej hospitalizacji, wyrażającego się w poszerzeniu tychże przesłanek poza „niebezpieczeństwo dla siebie i dla innych" i lepszego zrównoważenia wymogów medycznych i gwarancji prawnych ${ }^{7}$. O przyjęciu do szpitala psychiatrycznego osoby chorej psychicznie w tym trybie decyduje sąd opiekuńczy na wniosek wskazanych w art. 29 ust. 2 u.o.z.p. osób bliskich, ewentualnie na wniosek organu pomocy społecznej (art. 29 ust. 3 u.o.z.p.). Wskazać jeszcze należy na art. 33 ust. 1 u.o.z.p., który dopuszcza, w odniesieniu do osób przyjętych do szpitala psychiatrycznego bez zgody, przymusowe leczenie, włącznie z zastosowaniem przymusu bezpośredniego (art. 34 u.o.z.p.). Odróżnić bowiem należy zgodę na przyjęcie do szpitala psychiatrycznego od zgody na leczenie psychiatryczne ${ }^{8}$.

${ }^{4}$ P. Gałecki, K. Bobińska, K. Eichstaedt, Ustawa o ochronie zdrowia psychicznego. Komentarz, Warszawa 2016, s. 147.

${ }^{5}$ B. Janiszewska, Podmiotowe uwarunkowania hospitalizacji psychiatrycznej $w$ celu obserwacji, „Monitor Prawniczy” 2013, nr 3, Legalis, pkt III i IV.

${ }^{6}$ Wyrok SA w Krakowie z 18 lutego 2015 r., I ACa 1681/14, Legalis nr 1241969.

7 S. Dąbrowski, J. Pietrzykowski, Ustawa o ochronie zdrowia psychicznego. Komentarz, Warszawa 1997, s. 159-160; autorzy wskazuja (s. 25), że przymusowa hospitalizacja w modelu medycznym służy przede wszystkim do zaspokajania potrzeb zdrowotnych osób z zaburzeniami psychicznymi, a kwestie prawne zdecydowanie ustępuja procedurom medycznym. Zgodnie zaś z modelem prawnym przymusowa hospitalizacja jest głównie pozbawieniem wolności, a więc naruszeniem konstytucyjnych praw obywatelskich.

${ }^{8}$ D. Karkowska, Ustawa o prawach pacjenta i Rzeczniku praw pacjenta. Komentarz, Warszawa 2016, s. 361; S. Dąbrowski, J. Pietrzykowski, op. cit., s. 125-126. 


\section{KONWENCJA O PRAWACH OSÓB NIEPEŁNOSPRAWNYCH}

Konwencja nie tworzy żadnych nowych praw w odniesieniu do osób niepełnosprawnych, lecz ma na celu zapewnienie przestrzegania w stosunku do tej grupy osób już istniejących i uznanych praw człowieka. Przepis art. 1 Konwencji zawiera otwarty opis niepełnosprawności niebędący jej definicją. Zgodnie z nim do osób niepełnosprawnych zaliczają się m.in. osoby z długotrwale naruszoną sprawnością umysłowa. Wskazuje się, że zgodnie z oficjalnym, błędnym polskim tłumaczeniem Konwencji do osób niepełnosprawnych zaliczono osoby z niepełnosprawnością umysłową i intelektualna, mimo że określenia te dotyczą tej samy grupy osób; pominięto natomiast osoby z niepełnosprawnościa psychiczną ${ }^{10}$. Mimo to nie ulega wątpliwości, że osoby z zaburzeniami psychicznymi wchodzą w skład pojęcia osób niepełnosprawnych na gruncie Konwencji ${ }^{11}$. W literaturze zaznacza się także, że choć Konwencja mówi w art. 1 o długotrwałej niesprawności, jako jednej z przesłanek uznania osoby za niepełnosprawna, do osób tych zalicza się także osoby z krótkotrwałą niesprawnościa ${ }^{12}$. W art. 3 Konwencji ustanowiono jej podstawowe zasady, w tym m.in. zasadę niedyskryminacji. Pojęcie dyskryminacji zdefiniowano w art. 2 Konwencji, a zasadę niedyskryminacji osób niepełnosprawnych wyraźnie wyartykułowano w art. 5 Konwencji. Zasada ta przenika całość postanowień Konwencji i jest wielokrotnie przywoływana w jej szczegółowych zapisach. Treść zasady równości i niedyskryminacji polega na tym, że osoby w takich samych okolicznościach powinny być traktowane równo. Nie oznacza to jednak, że każde rozróżnienie czy odmienne traktowanie będzie oznaczało dyskryminację. Wskazuje się, że w prawie międzynarodowym naruszeniem zasady niedyskryminacji będzie sytuacja, w której a) takie same sprawy traktowane sa w sposób odmienny, b) różnica w traktowaniu nie ma obiektywnego i uzasadnionego usprawiedliwienia, c) brak proporcjonalności między postawionym celem a zaangażowanymi środkami ${ }^{13}$.

Dla celów niniejszego artykułu przytoczyć należy także treść art. 12 ust. 1 i 2 Konwencji, zgodnie z którym: „Państwa Strony potwierdzaja, że osoby niepełnosprawne maja prawo do uznania ich za podmioty prawa. Państwa Strony uznaja, że osoby niepełnosprawne maja zdolność prawna ${ }^{14}$, na zasadzie równości z innymi osobami, we wszystkich aspektach życia”. Zgodnie zaś z art. 14

${ }^{9}$ V. Della Fina, R. Cera, G. Palmisano (eds.), The United Nations Convention on the Rights of Persons with Disabilities: A Commentary, Springer International Publishing Switzerland 2017, s. 97.

${ }^{10}$ Realizacja przez Polske zobowiazań wynikajacych z Konwencji o prawach osób niepetnosprawnych. Sprawozdanie Rzecznika Praw Obywatelskich 2012-2014, Warszawa 2015, s. 14; $<$ https://www.rpo.gov.pl/sites/default/files/Sprawozdanie\%20KPON\%202015.pdf>.

${ }^{11}$ Wskazuje na to użycie słów „long-term [...] mental [...] impairments” w angielskim, autentycznym tekście Konwencji.

${ }^{12}$ V. Della Fina, R. Cera, G. Palmisano (eds.), op. cit., s. 99.

${ }^{13}$ Ibidem, s. 160.

${ }^{14}$ Użyty w angielskim, autentycznym tekście Konwencji termin „legal capacity” obejmuje zarówno zdolność prawna, jak i zdolność do czynności prawnych; zatem oficjalne polskie tłumaczenie tego terminu jest nieścisłe. 
ust. 1 Konwencji: „Państwa Strony zapewnia, że osoby niepełnosprawne, na zasadzie równości z innymi osobami: (a) będą korzystały z prawa do wolności i bezpieczeństwa osobistego, (b) nie będą pozbawiane wolności bezprawnie lub samowolnie, a także że każde pozbawienie wolności będzie zgodne z prawem oraz że niepełnosprawność w żadnym przypadku nie będzie uzasadniać pozbawienia wolności”. Artykuł 15 statuuje wolność od tortur oraz okrutnego, nieludzkiego lub poniżającego traktowania lub karania, art. 17 zaś ustanawia obowiązek poszanowania integralności fizycznej i psychicznej osoby niepełnosprawnej na zasadzie równości z innymi osobami. Zgodnie zaś z art. 25 ust. 1 zd. 1: „Państwa Strony uznaja, że osoby niepełnosprawne maja prawo do osiagnięcia najwyższego możliwego poziomu stanu zdrowia, bez dyskryminacji ze względu na niepełnosprawność. Wedle art. 25 ust. 1 pkt d) Państwa Strony zobowiążą osoby wykonujące zawody medyczne do zapewniania osobom niepełnosprawnym, na podstawie swobodnie przez nie wyrażonej i świadomej zgody, opieki takiej samej jakości jak innym osobom [...]”.

Dodać do tego należy, że na mocy art. 34 ust. 1 Konwencji ustanowiono Komitet ds. Praw Osób Niepełnosprawnych, którego głównym zadaniem jest rozpatrywanie sprawozdań państw stron Konwencji dotyczących środków podjętych w celu realizacji zobowiązań wynikających z Konwencji (art. 35 ust. 1 Konwencji) i wydawanie uwag i zaleceń państwom stronom Konwencji (art. 36 ust. 1 Konwencji).

\section{STANOWISKO KOMITETU DS. PRAW OSÓB NIEPEENOSPRAWNYCH}

Rozważając zgodność przepisów u.o.z.p. z zapisami Konwencji, wskazać należy na stanowisko Komitetu ds. Praw Osób Niepełnosprawnych w zakresie analogicznych do polskich uregulowań, wyrażone w Ogólnym komentarzu nr 1 z 2014 r. dotyczącym art. 12 Konwencji ${ }^{15}$ oraz w Wytycznych do art. 14 Konwencji o prawach osób niepełnosprawnych - prawo do wolności i bezpieczeństwa osób niepełnosprawnych, przyjętych podczas 14 sesji Komitetu we wrześniu 2015 r. ${ }^{16} \mathrm{~W}$ obu wymienionych dokumentach Komitet zakwestionował zgodność z Konwencją regulacji zezwalajacych na przymusową hospitalizację i leczenie psychiatryczne także w sytuacji, gdy regulacje te przewidywały poza przesłanką choroby psychicznej także dodatkowe przesłanki behawioralne, jak choćby zagrożenie dla siebie lub innych. W ocenie Komitetu regulacje takie naruszaja art. 12, 14, 15, 17 i 25 Konwencji, a także zakaz niedyskryminacji. Komitet wskazał, że podczas negocjacji co do treści Konwencji celowo zrezygnowano ze słowa „wyłącznie” w art. 14 ust. 1 pkt b Konwencji. W konsekwencji art. 14 ust. 1 pkt b zakazuje pozbawienia wolności na podstawie

15 General Comment No. 1 (2014), Article 12: Equal recognition before the law, <http://tbinternet.ohchr.org/_layouts/treatybodyexternal/Download.aspx?symbolno=CRPD/C/GC/1\&Lang=en>.

${ }^{16}$ Guidelines on article 14 of the Convention on the Rights of Persons with Disabilities. The right to liberty and security of persons with disabilities, <http://www.ohchr.org/EN/HRBodies/ CRPD/Pages/CRPDIndex.aspx>. 
realnej lub postrzeganej niepełnosprawności, nawet jeśli użyto dodatkowych czynników lub kryteriów do uzasadnienia pozbawienia wolności ${ }^{17}$. W ocenie Komitetu podstawą leczenia, także psychiatrycznego, w myśl Konwencji może być wyłącznie swobodna i świadoma zgoda pacjenta ${ }^{18}$. Komitet wskazał także na konieczność zapewnienia przez państwa strony Konwencji pacjentom z zaburzeniami psychicznymi niemedycznego podejścia do ich problemów zdrowotnych $^{19}$. Stanowisko to znajduje potwierdzenie w literaturze, gdzie wskazuje się, że przymusowa hospitalizacja osoby niepełnosprawnej psychicznie będzie niezgodna $\mathrm{z}$ Konwencja, nawet jeśli jej podstawą będzie niepełnosprawność psychiczna oraz inne elementy, zgodnie bowiem z art. 14 ust. 1 pkt b Konwencji niepełnosprawność w żadnym razie nie może legitymizować pozbawienia wolności ${ }^{20}$. Wskazuje się jednak, że przymusowa hospitalizacja osoby niepełnosprawnej psychicznie może być uznana za zgodną z art. 14 Konwencji, jeśli następuje na podstawie postanowienia neutralnego wobec niepełnosprawności, jak choćby ochrona porządku publicznego ${ }^{21}$. Z tym ostatnim stwierdzeniem nie można się zgodzić, ponieważ nawet jeśli pozbawienie wolności osoby niepełnosprawnej następowałoby na podstawie pozornie neutralnego kryterium, w praktyce jednak dotyczyłoby przede wszystkim osób z niepełnosprawnościa psychiczna, można by uznać taka regulację za dyskryminację pośrednia, zakazaną w myśl art. 5 Konwencji oraz art. 14 Konwencji w związku z art. $2^{22}$.

\section{ZGODNOŚĆ PRZEPISÓW U.O.Z.P. Z KONWENCJĄ - ART. 23 UST. 1 ORAZ ART. 24 U.O.Z.P.}

Analizę zgodności polskiej u.o.z.p. z Konwencją należy rozpocząć od art. 23 ust. 1 u.o.z.p. Przepis ten zezwala na prewencyjne pozbawienie wolności w stosunku do osób chorych psychicznie, mimo że osoby te nie popełniły żadnego czynu zabronionego. Podstawą pozbawienia wolności na podstawie tego przepisu jest bowiem bezpośrednie zagrożenie życia własnego albo życia lub zdrowia innych osób ${ }^{23}$. W stosunku do ogółu zaś przesłanką pozbawienia wolności jest dopiero wyrok orzekający karę pozbawienia wolności z tytułu popełnionego przestępstwa, ewentualnie uzasadnione przypuszczenie popełnienia

17 Ibidem, pkt 7.

18 General Comment No. 1 ..., pkt 41.

19 Ibidem, pkt 42.

20 V. Della Fina, R. Cera, G. Palmisano (eds.), op. cit., s. 295-296.

21 Ibidem, s. 295.

22 T. Minkowitz, Why Mental Health Laws Contravene the CRPD-An Application of Article 14 with Implications for the Obligations of States Parties, pkt 7, <https://ssrn.com/abstract=1928600, http://dx.doi.org/10.2139/ssrn.1928600>.

${ }^{23} \mathrm{~W}$ literaturze wskazuje się, że istnienie zagrożenia oznacza stan realnego niebezpieczeństwa wynikający z aktualnego stanu zdrowia psychicznego pacjenta, mogacy skutkować spowodowaniem śmierci samego pacjenta lub innych osób albo uszczerbek na zdrowiu tych ostatnich osób; natomiast bezpośredniość zagrożenia dla określonych dóbr (np. życia, zdrowia), oznacza, że szkoda może nastapić w każdej chwili lub w stosunkowo niedalekiej przyszłości, jest nieuchronna - por. J. Duda, Komentarz do ustawy o ochronie zdrowia psychicznego, Warszawa 2012, s. 236. 
przestępstwa, będące podstawą zatrzymania (art. $244 \S 1$ k.p.k.). Samo bezpośrednie zagrożenie życia własnego albo życia lub zdrowia innych osób nie jest podstawą pozbawienia wolności na podstawie przepisów ustawy karnej. Ustawa ta penalizuje przygotowanie (art. 16 k.k. - tylko wtedy, gdy ustawa tak stanowi) oraz usiłowanie (art. 13 k.k.), które zachodzi wówczas, gdy dana osoba w zamiarze popełnienia czynu zabronionego swoim zachowaniem bezpośrednio zmierza do jego dokonania, które jednak nie następuje. Samo zaś bezpośrednie zagrożenie życia własnego albo życia lub zdrowia innych osób nie jest jeszcze usiłowaniem. Sformułowanie to stanowi nie tyle obiektywna próbę wyodrębnienia fragmentu zachowania danej osoby jako zmierzającego do naruszenia porządku prawnego, ile raczej opiera się na przewidywaniu czy obawie opartej na dotychczasowym zachowaniu osoby chorej psychicznie, że może ona przeciwko temu porządkowi wystapić.

Przykładem takiego sposobu myślenia jest wyrok Sąu Apelacyjnego w Warszawie z 21 maja 2013 r. (I ACa 1425/12, Legalis nr 722821), w którym powód, żądający zadośćuczynienia od szpitala psychiatrycznego ze względu na bezprawna w jego ocenie hospitalizację, został przyjęty do szpitala m.in. dlatego, że w łóżku trzymał nóż oraz nosił ze sobą młotek. Sąd Apelacyjny uznał, że to zachowanie, z uwzględnieniem innych okoliczności (takich jak obawy o otrucie przez domowników, negatywne nastawienie do żony, nadmierna aktywność, zaprzestanie przyjmowania leków i posiłków, bezsenność, poczucie doskonałości, zaobserwowanymi wskutek rozpoznania zespołu maniakalnego z objawami psychosomatycznymi), stanowiło dostateczną podstawę do pozbawienia powoda wolności w szpitalu psychiatrycznym. W przykładzie tym pacjent nie popełnił żadnego czynu zabronionego przez prawo - niemniej jego zachowanie zostało uznane za bezpośrednio zagrażające życiu lub zdrowiu innych osób. Obawiano się bowiem, że może on popełnić czyn zabroniony. Jednakże czym innym jest możliwość popełnienia czynu zabronionego, a czym innym bezpośrednie zmierzanie do jego dokonania. Jak wynika z powyższego, osoby z niepełnosprawnością psychiczną są traktowane w sposób odmienny od ogółu społeczeństwa w zakresie przesłanek pozbawienia wolności.

W tym miejscu wskazać należy, że zachowanie osób chorych psychicznie nierzadko jest nieracjonalne, dziwaczne, odbiegajace od przyjętych norm społecznych. Powoduje to lęk u osób postronnych, niemogacych racjonalnie przewidzieć zachowania takiej osoby i zrozumieć motywów, jakimi się kieruje. Z tego wynika, że ocena zachowania takiej osoby przez innych jest naznaczona piętnem uprzedzeń i niezrozumienia. Te postawy osób z zewnątrz uznać należy za bariery, w rozumieniu pkt e) preambuły oraz art. 1 Konwencji, utrudniające osobom z niepełnosprawnością psychiczną pełny i skuteczny udział w życiu społecznym, na zasadzie równości z innymi osobami. Celem Konwencji jest usunięcie tych barier, tak aby także osoby z niepełnosprawnościa psychiczną mogły korzystać z pełni praw człowieka gwarantowanych przez prawo międzynarodowe i krajowe. Droga ku temu jest przede wszystkim usunięcie z systemu prawnego dyskryminujących osoby niepełnosprawne przepisów krajowych. W konsekwencji wskazać należy, że art. 23 u.o.z.p. ma charakter dyskryminacyjny w stosunku do osób 
z niepełnosprawnością psychiczna. Przewiduje bowiem dla osób z tego typu dysfunkcją odmienną regulację prawną w zakresie przesłanek pozbawienia wolności niż dla ogółu społeczeństwa. Podstawą bowiem pozbawienia wolności osoby chorej psychicznie nie jest popełnienie przez nią przestępstwa, lecz obawa, że może ona dopuścić się czynu na szkodę własną lub innej osoby. Przy czym obawa ta, jak wskazano wyżej, ma podstawy nie w racjonalnym rozumowaniu, ale w uprzedzeniach i niezrozumieniu osób chorych psychicznie. Nie można zatem powiedzieć, że opisane wyżej różne traktowanie osób z niepełnosprawnością psychiczną i ogółu społeczeństwa, w zakresie przesłanek pozbawienia wolności, ma obiektywne i uzasadnione usprawiedliwienie, pozwalające przyjąć, że nie mamy tu do czynienia z dyskryminacją. Skoro zaś art. 14 ust. 1 Konwencji stanowi o prawie do wolności i nietykalności osobistej „na zasadzie równości z innymi osobami”, to przepisy dyskryminujące osoby z niepełnosprawnością psychiczną w tym zakresie uznać należy za niezgodne z Konwencją.

Nie oznacza to oczywiście, że osoby chore psychicznie nie będą odpowiadać za swoje zachowanie: gdy osoba chora psychicznie popełni przestępstwo, winna ona być ukarana zgodnie z przepisami prawa krajowego, a jej stan psychiczny uwzględniony przy analizie strony podmiotowej czynu zabronionego ${ }^{24}$. Komitet ds. Praw Osób Niepełnosprawnych we wspomnianych już Wytycznych do art. 14 Konwencji o prawach osób niepełnosprawnych - prawo do wolności i bezpieczeństwa osób niepełnosprawnych, uznał regulacje traktujące osoby niepełnosprawne jako niezdolne do uczestniczenia w procesie karnym i nieponoszące odpowiedzialności karnej za niezgodne z art. 14 Konwencji ${ }^{25}$. Stanowisko to jest zbieżne z poglądami wyrażanymi przez przedstawicieli tzw. antypsychiatrii. Twierdzą oni, że problemy nazywane „chorobą psychiczną" nie sa w istocie zagadnieniami medycznymi, lecz raczej problemami etycznymi i moralnymi, związanymi z odpowiedzią na pytanie, jak człowiek powinien żyć ${ }^{26}$. W konsekwencji domagają się oni usunięcia z systemu prawnego regulacji zezwalających na przymusowa hospitalizację i leczenie psychiatryczne, a także regulacji uwalniających osoby z zaburzeniami psychicznymi od odpowiedzialności karnej - są to bowiem regulacje „obwiniające niewinnych i ekskulpujące winnych" 27 .

W doktrynie zaznacza się, uzasadniając potrzebę przymusowej hospitalizacji i leczenia psychiatrycznego, że zmiany psychotyczne są wyrazem przejściowego albo trwałego ograniczenia autonomii chorego psychicznie ${ }^{28}$. Podkreśla

${ }^{24}$ T. Minkowitz, Rethinking criminal responsibility from a critical disability perspective: the abolition of insanity/incapacity acquittals and unfitness to plead, and beyond, „Griffith Law Review" 23(3), 2014, s. 434-466.

${ }_{25}$ Guidelines on article $14 \ldots$, pkt 16.

26 T. Szasz, Mit choroby psychicznej, w: K. Jankowski (red.), Przełom w psychologii, Warszawa 1978 , s. 237.

27 T. Szasz, The case against psychiatric coercion, „The Independent Review” 1(4), 1997, s. 497, <http://www.independent.org/pdf/tir/tir_01_4_szasz.pdf>; autor ten wskazuje także, że samobójstwo jest wyrazem ludzkiej wolności i błędne jest jego traktowanie jako choroby - por. idem, The Ethics of Suicide, ,The Antioch Review” 31(1), 1971, s. 7-17.

28 S. Dąbrowski, J. Pietrzykowski, op. cit., s. 136. 
się, że zewnętrzne ograniczenie wolności w formie przymusowej hospitalizacji jest tym bardziej uzasadnione, im bardziej upośledzona jest autonomia pacjen$\mathrm{ta}^{29}$. Jednakże takie stanowisko na gruncie Konwencji jest nieuzasadnione. Nawet bowiem w sytuacji, gdy sposób postrzegania, myślenia czy zachowania osoby z niepełnosprawnością psychiczną wydaje się upośledzony, nie jest to podstawa do odbierania tym osobom praw określonych międzynarodowymi standardami praw człowieka. Celem Konwencji jest bowiem, jak wskazano wyżej, zapewnienie, że te standardy będą respektowane także w odniesieniu do osób niepełnosprawnych, w tym niepełnosprawnych psychicznie. Konwencja zaś chroni godność, autonomię osoby niepełnosprawnej, w tym swobodę dokonywania wyborów, a także poszanowanie niezależności tej osoby (art. 3 pkt a) Konwencji). Pojęcie godnościludzkiej, zawarte również w art. 30 Konstytucji RP ${ }^{30}$, wyraża cywilizacyjny aksjomat, zgodnie z którym każdy człowiek posiada wewnętrzna niezbywalną wartość, niezależna od cech osobniczych lub własnych zachowań, niezbywalna jakościowo odmienną od innych bytów ${ }^{31}$. Poszanowanie zaś autonomii osoby niepełnosprawnej to prawo do rozwijania swojej osobowości, do uczestniczenia w procesie politycznym, prawo do prywatności, do integralności i do bycia włączonym w życie społeczności ${ }^{32}$.

Zasada niezależności zakłada natomiast nie tylko prawo do dokonywania wyborów w odniesieniu do sfery prywatnej w sposób wolny i świadomy, lecz także prawo do brania aktywnego udziału w otoczeniu społecznym ${ }^{33}$. Powyższe zasady Konwencji kładą zatem nacisk na upodmiotowienie osób niepełnosprawnych, dając im prawo do samodzielnego decydowania o własnym losie; dotyczy to także tych, których sposób postrzegania rzeczywistości, myślenia i zachowania wydaje się zaburzony. W konsekwencji żadne oceny dokonywane przez osoby z zewnątrz nie mogą zastapić prawa osoby niepełnosprawnej do podejmowania autonomicznych decyzji co do własnego życia, choćby te decyzje wydawały się nieracjonalne, ułomne czy dziwaczne. Autonomiczne i niezależne decyzje osoby niepełnosprawnej musza bowiem być respektowane przez system prawny; system ten musi zapewnić poszanowanie praw, woli i preferencji osób niepełnosprawnych (art. 12 ust. 4 Konwencji) i nikt nie może osób tych w tym zakresie zastapić. Dotyczy to oczywiście także, a może nawet przede wszystkim, przedstawicieli profesji medycznej, w tym psychiatrów. Artykuł 23 ust. 1 u.o.z.p. nie spełnia tych wymagań, stawiając oceny osób z zewnątrz - prawników czy lekarzy psychiatrów - i ich decyzje ponad wolę i preferencje osób niepełnosprawnych psychicznie. W konsekwencji przepis ten uznać należy za niezgodny z zasadami Konwencji i majaccy charakter dyskryminacyjny. Niezgodność ta dotyczy zatem także art. 24 u.o.z.p., który w zakresie przesłanek stosowania zawiera regulacje analogiczne do art. 23 u.o.z.p. (art. 24 ust. 3 u.o.z.p.).

29 Ibidem.

${ }^{30}$ Konstytucja Rzeczypospolitej Polskiej z 2 kwietnia 1997 r., Dz. U. Nr 78, poz. 483 ze zm.

31 M. Safjan, L. Bosek (red.), Konstytucja RP, t. 1: Komentarz do art. 1-86, Warszawa 2016, Legalis, Komentarz do art. 30, pkt I.2.

${ }^{32}$ V. Della Fina, R. Cera, G. Palmisano (eds.), op. cit., s. 124.

33 Ibidem, s. 125. 


\section{ZGODNOŚĆ PRZEPISÓW U.O.Z.P. Z KONWENCJĄ - ART. 29 UST. 1 U.O.Z.P.}

Należy także rozważyć zgodność z Konwencją art. 29 ust. 1 u.o.z.p., przewidującego wnioskowy tryb przyjęcia do szpitala psychiatrycznego pacjenta chorego psychicznie bez zgody. Wskazać należy, że przepis ten opiera się w zasadzie na czysto medycznych przesłankach hospitalizacji osób chorych psychicznie bez zgody. Oznacza to, że w tych przypadkach niepełnosprawność jest podstawą pozbawienia wolności, a to w myśl art. 14 ust. 1 pkt b Konwencji, jest zakazane. Użycie bowiem w art. 29 ust. 1 u.o.z.p. oprócz przesłanki choroby psychicznej także innych przesłanek o charakterze medycznym nie zmienia faktu, że w tych przypadkach to niepełnosprawność psychiczna jest zasadniczą podstawa pozbawienia wolności w szpitalu psychiatrycznym, a dodatkowe przesłanki medyczne jedynie tę podstawę doprecyzowuja.

Dodać też należy, że szerokie traktowanie w orzecznictwie przesłanki zawartej w art. 29 ust. 1 pkt 1 u.o.z.p. - jako doprowadzenie się przez osobę chorą psychicznie, na skutek niepodejmowania leczenia, do stanu uniemożliwiającego jej funkcjonowanie w rodzinie, w miejscu zamieszkania lub w pra$\mathrm{cy}^{34}$ - także będzie trudne do pogodzenia z celami i zasadami Konwencji. Jak wskazywano bowiem już wyżej, Konwencja kładzie nacisk na autonomię i niezależność osób z niepełnosprawnością psychiczną (art. 3 a), pozostawiając im swobodę decyzji co do osobistej sfery życia, takiej jak choćby praca, otoczenie społeczne, rodzina, i domaga się respektowania tych decyzji przez osoby postronne. Oznacza to, że osoby niepełnosprawne psychicznie nie moga podlegać ocenom zewnętrznych, „racjonalnych” obserwatorów i być zmuszane do podporządkowania się ich decyzjom, lecz samodzielnie musza rozstrzygać o tym, co jest dla nich dobre, niezależnie od tego, co na ten temat sądzą osoby z zewnątrz. Znajduje to wyraz w art. 12 ust. 4 Konwencji, gdzie wskazuje się, że zabezpieczenia dotyczące środków związanych z korzystaniem ze zdolności prawnej ${ }^{35}$ muszą respektować prawa, wolę i preferencje osoby niepełnosprawnej. Razem ze wspomnianymi wyżej zasadami autonomii i niezależności osób niepełnosprawnych Konwencja wskazuje na zupełnie odmienne od dotychczasowego spojrzenie na problematykę związaną z osobami z zaburzeniami psychicznymi. Jeśli zatem nawet osoba taka doprowadzi się do stanu uniemożliwiającego jej funkcjonowanie w rodzinie, w miejscu zamieszkania lub w pracy - to w świetle Konwencji będzie to wyłącznie jej autonomiczna decyzja, za którą odpowiedzialność ponosić będzie ta osoba; z pewnościa nie może to być podstawa do pozbawienia jej wolności w szpitalu psychiatrycznym i wdrożenia przymusowego leczenia.

${ }^{34}$ Por. postanowienia SN: z 25 listopada 2016 r., V CSK 295/16, Legalis nr 1560065; z 5 listopada 2015 r., V CSK 456/15, Legalis nr 1381878; z 22 kwietnia 2010 r., V CSK 384/09, Legalis nr 381618; por. także S. Dąbrowski, J. Pietrzykowski, op. cit., s. 160.

${ }^{35}$ Chodzi tu o zdolność do czynności prawnych - por. General Comment No. 1..., pkt 12. 


\section{ZGODNOŚĆ PRZEPISÓW U.O.Z.P. Z KONWENCJĄ - ART. 33 UST. 1 ORAZ ART. 34 U.O.Z.P.}

Kolejnym przepisem u.o.z.p., którego zgodność z Konwencją wymaga zbadania, jest art. 33 ust. 1 u.o.z.p. łącznie z doprecyzowującym go art. 34 u.o.z.p. Przepisy te regulują dopuszczalność przymusowego leczenia osób przyjętych do szpitala psychiatrycznego bez ich zgody i zezwalają na stosowanie w stosunku do tych osób w tym celu przymusu bezpośredniego. Wskazać w tym kontekście należy, że zgodnie z art. 16 ustawy o prawach pacjenta i Rzeczniku Praw Pacjenta z 6 listopada 2008 r. ${ }^{36}$ pacjent ma prawo do wyrażenia zgody na udzielenie określonych świadczeń zdrowotnych lub odmowy takiej zgody, po uzyskaniu informacji w zakresie określonym w art. 9. Artykuł 16 u.p.p. przyjmuje - w płaszczyźnie polskiego prawa medycznego - solidnie już ustaloną zasadę, że żadnego świadczenia (interwencji) nie można nikomu narzucić bez jego zgody ${ }^{37}$. Artykuł 33 ust. 1 u.o.z.p. jest jednym z wyjątków od powyższej reguły ${ }^{38}$, stanowiąc, że wobec osoby przyjętej do szpitala psychiatrycznego bez jej zgody można stosować niezbędne czynności lecznicze, mające na celu usunięcie przewidzianych w ustawie przyczyn przyjęcia bez zgody. Przepis ten jest logiczną konsekwencją uregulowań zezwalających na przymusową hospitalizację osób chorych psychicznie, sama bowiem przymusowa hospitalizacja bez leczenia psychiatrycznego byłaby sprzeczna z elementarna motywacja decyzji o przymusowej hospitalizacji ${ }^{39}$. Zgoda pacjenta na świadczenia zdrowotne jest wyrazem prawa pacjenta do dysponowania swoim ciałem i stanowi jednostronne oświadczenie woli o charakterze upoważniającym i odwoływalnym ${ }^{40}$. Jednym $\mathrm{z}$ warunków udzielenia skutecznej zgody na czynności medyczne jest zdolność do czynności prawnych. Przymusowe leczenie psychiatryczne osoby chorej psychicznie stanowi zatem przejaw odebrania tym osobom zdolności do czynności prawnych w zakresie wyrażania zgody na udzielanie świadczeń zdrowotnych. Stanowi to naruszenie art. 12 ust. 2 Konwencji, gwarantującego osobom z niepełnosprawnościa psychiczną zdolność do czynności prawnych, na zasadzie równości z innymi osobami, we wszystkich aspektach życia. Artykuł 12 ust. 2 Konwencji rozumieć zatem należy jako gwarancję zdolności do czynności prawnych osób z niepełnosprawnością psychiczną także na gruncie prawa medycznego, w tym ustawy o ochronie zdrowia psychicznego.

Co więcej, wskazać należy także na art. 25 pkt d) Konwencji, stanowiący, że opieka medyczna nad osobami z niepełnosprawnością winna opierać się na świadomej i swobodnej zgodzie tych osób. Dotyczy to także, a może na-

36 T.jedn.: Dz. U. 2017, poz. 1318 ze zm. (dalej jako: u.p.p.).

37 D. Karkowska, op. cit., s. 313

38 Por. także art. $26 \mathrm{w}$ zw. z art. 24 ustawy o wychowaniu w trzeźwości i przeciwdziałaniu alkoholizmowi z 26 października 1982 r. (Dz. U. Nr 35, poz. 230 ze zm.) oraz art. 30 ustawy o przeciwdziałaniu narkomanii z 29 lipca 2005 r. (Dz. U. Nr 179, poz. 1485 ze zm.).

39 Por. S. Dąbrowski, J. Pietrzykowski, op. cit., s. 169-170.

${ }^{40}$ D. Karkowska, op. cit., s. 319. 
wet przede wszystkim, osób z niepełnosprawnością psychiczną. Konsekwencja tego przepisu jest to, że przymusowe leczenie psychiatryczne będzie niezgodne $\mathrm{z}$ Konwencją ${ }^{41}$. Przytoczyć należy także raport specjalnego sprawozdawcy ONZ w sprawie tortur i innego okrutnego, nieludzkiego lub poniżającego traktowania lub karania z $2008 \mathrm{r} .{ }^{42}$ Wskazał on w tym dokumencie, że przymusowe podawanie leków psychotropowych, w tym w szczególności neuroleptyków, w zależności od okoliczności sprawy, spowodowanego cierpienia oraz efektów zdrowotnych, może stanowić formę tortury lub złego traktowania ${ }^{43}$. Stanowisko to zostało potwierdzone w raporcie tego sprawozdawcy z 2013 r., który wskazał w nim, że przymusowe leczenie psychiatryczne w zakresie, w jakim powoduje poważny ból i cierpienie, narusza absolutny zakaz tortur i okrutnego, nieludzkiego i poniżającego traktowania ${ }^{44}$. W tych przypadkach przymusowe leczenie psychiatryczne będzie niezgodne z art. 15 Konwencji. W literaturze zaznacza się również, że przymusowe leczenie psychiatryczne stanowić będzie naruszenie art. 17 Konwencji, dotyczącego poszanowania integralności fizycznej i psychicznej osoby z niepełnosprawnością ${ }^{45}$. Przepis ten jest bowiem ściśle powiązany z art. 12 Konwencji i naruszenie prawa do integralności jest zarazem jego naruszeniem ${ }^{46}$.

\section{PODSUMOWANIE}

W konsekwencji stwierdzić należy, że przepisy u.o.z.p., zarówno art. 23 ust. 1, art. 24, jak i art. 29 ust. 1, regulujące przymusową hospitalizację osoby chorej psychicznie, a także art. 33 ust. 1 i 34 u.o.z.p., zezwalające na przymusowe leczenie farmakologiczne takiej osoby, sa niezgodne z Konwencja o prawach osób niepełnosprawnych, w tym przede wszystkim z jej art. 12, 14, 15, 17 oraz 25. Tezę tę potwierdza także opisane wyżej stanowisko Komitetu ds. Praw Osób Niepełnosprawnych. Ponieważ Konwencja została ratyfikowana za uprzednią zgodą wyrażoną w ustawie ${ }^{47}$, ma ona pierwszeństwo przed u.o.z.p., jeśli ustawy tej nie da się pogodzić z umową (art. 91 ust. 2 Konstytucji RP). Zatem wraz z wejściem w życie Konwencji brak w Polsce podstaw prawnych do przymusowej hospitalizacji i leczenia psychiatrycznego. Konwencja wyznacza zupełnie nowe standardy w zakresie postępowania z osobami z zaburzenia-

${ }^{41}$ V. Della Fina, R. Cera, G. Palmisano (eds.), op. cit., s. 470.

${ }^{42} \mathrm{M}$. Nowak, Interim report of the Special Rapporteur on torture and other cruel, inhuman or degrading treatment or punishment, 28.07.2008, A/63/175, <www.un.org/disabilities/ images/A.63.175.doc>.

43 Ibidem, pkt 63.

44 J.E. Mendez, Report of the Special Rapporteur on torture and other cruel, inhuman or degrading treatment or punishment, 1.02.2013, A/HRC/22/53, pkt 64, <http://www.ohchr.org/Documents/HRBodies/HRCouncil/RegularSession/Session22/A.HRC.22.53_English.pdf>.

${ }^{45}$ V. Della Fina, R. Cera, G. Palmisano (eds.), op. cit., s. 331.

46 Ibidem.

47 Ustawa z 15 czerwca 2012 r. o ratyfikacji Konwencji o prawach osób niepełnosprawnych, sporządzonej w Nowym Jorku dnia 13 grudnia 2006 r., Dz. U. 2012, poz. 882. 
mi psychicznymi, które stanowić mogą - i mam nadzieję, że będą - zupełnie nową jakość w tym zakresie. Godny podkreślenia jest fakt wskazania przez Komitet ds. Praw Osób Niepełnosprawnych na konieczność zaoferowania pacjentom z zaburzeniami psychicznymi niemedycznego podejścia do ich problemów zdrowotnych, co z pewnością wyjdzie naprzeciw oczekiwaniom wielu $\mathrm{z}$ nich, rozczarowanych tradycyjnym leczeniem farmakologicznym, wiążącym się nierzadko z licznymi dolegliwościami. Tym samym można powiedzieć, że uchwalenie Konwencji i powołanie Komitetu rozpoczynaja zupełnie nowy rozdział w zakresie leczenia i opieki nad osobami z zaburzeniami psychicznymi; miejmy nadzieję, że będzie to z korzyścią dla pacjentów i całego społeczeństwa.

mgr Michat Czubala

Sad Okregowy w Poznaniu

mczubala@op.pl

\section{FORCED PSYCHIATRIC TREATMENT IN THE LIGHT OF THE UN CONVENTION ON THE RIGHT OF PERSONS WITH DISABILITIES}

\section{Summary}

The main purpose of this paper is to analyse the conformity of the provisions of the Act of 19 August 1994 on the Protection of Mental Health with the provisions of the UN Convention on the Rights of Persons with Disabilities of 13 December 2006 (CRPD). The paper describes the particular provisions of the Act on the Protection of Mental Health that allow forced treatment of the mentally ill, and the provisions of the CRPD on that matter. The stance of the Committee on the Rights of Persons with Disabilities which questions the legality of forced treatment of mentally ill in the light of the CRPD is presented, followed by the author's own view. It is concluded that the provisions of the Act on the Protection of Mental Health which permit forced treatment of the mentally ill are inconsistent with the provisions of the CRPD, in particular with Articles 12, 14, 15, 17 and 25. The provisions of the CRPD, as discussed in this paper, do not allow deprivation of liberty based on disability including cases where the legislation provides additional premises for deprivation of liberty, for example threatening one's life or life and health of others. According to the CRPD, medical treatment, including psychiatric treatment, may be provided only on the basis of free and informed consent. Based on the above there is lack of legal grounds for forced treatment of mentally ill, as the international agreement ratified with the prior consent expressed in the act has the priority over the act if it is not consistent with the international agreement (Article 91 par. 2 of the Constitution). 